\section{Improvement of production standards in a company leader in the poultry meat market: the competent authority's role}

\author{
Monica Gramenzi, ${ }^{1}$ Oana Guerrieri, ${ }^{2}$ \\ Emidio Di Pancrazio, ${ }^{3}$ Luca Pennisi, ${ }^{1}$ \\ Alberto Vergara'
}

'Scuola di Specializzazione in Ispezione degli Alimenti di Origine Animale G. Tiecco, Università degli Studi di Teramo, Teramo; ${ }^{2}$ Servizio Igiene Alimenti - AUSL 4 Teramo; ${ }^{3}$ Laboratori di AssicurazioneQualità del gruppo Amadori, San Vittore di Cesena, Italy

\section{Abstract}

The object of this study was to evaluate, in a company that is leader in the production of poultry meat, the effects of the combined action between the official veterinary controls and the food business operator (FBO) on corporate manufacturing standards. To this purpose, the corporate documentation have been examined (inspection reports and audits of official veterinary controls and data obtained by self-control procedures) on a four-year period between 2008 and 2011. The results obtained showed that, despite the application of specific procedures by the FBO, the competent authority has observed a number of non-compliances, grouped into four main areas: cleaning and disinfection, maintenance in the plant, staff training, management of animal by-products. The immediate response of the FBO for the resolution of the non-compliances resulted in an overall significant improvement in hygiene and safety of products and processes, a gradually reduced number of non-compliance reports, a decrease of all microbiological parameters and the extension of products' shelf life.

\section{Introduction}

In recent years, under the impact of significant changes to the relevant community legislation and rapid changes in the balance of the market, the organisation and structure of the poultry production chain has experienced profound changes. The leading industries have had to implement and maintain highly effective food safety management systems (FSMS) able to sustain high production rates and to ensure adequate shelf life at large volumes of highly perishable product.

The high degree of corporate maturity results in the correct implementation of proce- dures based on the principles of hazard analysis and critical control points (HACCP) and other procedures to verify compliance with hygiene, in full respect of binding regulations (Reg. EC n. 852/2004, Reg. EC n. 854/2004, Reg. EC n. 2073/2005) (European Union, 2004a, 2004b, 2005), and very often voluntary. The role of the competent authority in these evolved realities remains central in the course towards the optimization of the food safety management system. For the purpose it was considered interesting to evaluate over a period of four years, the role of veterinary services in a leading company in the sector and the margin of improvement that the competence of the Authority in one hand, and the awareness of the importance of invest in food safety by the company on the other, in a spirit of active cooperation, has allowed to achieve.

\section{Materials and Methods}

In the 2008-2011 period, the activity of official control held constantly by the hygiene veterinary service for animal origin food of territorial competence in a leading company in the production of poultry meat was evaluated. To this purpose, the documents for all activities have been analysed, considering the inspection reports, audit reports, and the results of the microbiological analyzes provided in the sampling plan of the manual of corporate selfcontrol. Specifically, they have been subject of control areas of the slaughter and cutting, with the relevant production lines. The research of microbiological parameters of skin samples and environmental pre-operative, took place using validated methods below: total mesophilic charge (TMC) (UNI EN ISO 4833:2004) (UNI EN ISO, 2004); total coliforms (ISO 4832:1991) (ISO, 1991); Escherichia coli (UNI EN ISO 16649-2:2010) (ISO, 2010); Salmonella spp. (UNI EN ISO 6579:2008) (UNI EN ISO, 2008); coagulase positive Staphylococci (UNI EN ISO 10984-2:2002) (UNI EN ISO, 2002); Pseudomonas spp. (AFNOR V04-504) (AFNOR, 2006); environmental swabs (UNI EN ISO 4833:2004, ISO 18593:2004) (UNI EN ISO, 2004; ISO, 2004). In the same period indipendent shelf life tests were conducted by the company on different types of fresh product packed in trays with permeable plastic film. The first indipendent shelf-life tests were carried out in 2008 and 2011 in a total of 20 samples to compare the microbiological parameters (TMC, E. Coli, Pseudomonas spp.) on fresh products stored at $+4^{\circ} \mathrm{C}$. The second indipendent test was carried out in 2011 in a total of 14 sample to compare the microbiological parameters (TMC, E. Coli, Pseudomonas spp.) on fresh products stored at temperature of $+4^{\circ} \mathrm{C}$ (storage temperature in
Correspondence: Monica Gramenzi, Scuola di Specializzazione in Ispezione degli Alimenti di Origine Animale G. Tiecco, Università degli Studi di Teramo, viale Crucioli 122, 64100 Teramo, Italy Tel. +39.347.3111830 - Fax: +39.0861.781026.

E-mail: gramenzivet@gmail.com

Key words: Official control, Poultry, Production standards.

Conflict of interests: the authors declare no potential conflict of interests.

Received for publication: 4 February 2013.

Revision received: 29 March 2013.

Accepted for publication: 9 April 2013.

This work is licensed under a Creative Commons Attribution 3.0 License (by-nc 3.0).

(C) Copyright et al., 2013

Licensee PAGEPress, Italy

Italian Journal of Food Safety 2013; 2:e29

doi:10.4081/ijfs.2013.e29

the legislation) and $+8^{\circ} \mathrm{C}$ (temperature presumably present at home) (Vergara et al. 2010). Statistical analysis and standard deviation of data obtained from microbiological analysis were calculated using Microsoft Excel $^{\odot} 2010$.

\section{Results}

The major non-conformities identified during the inspection activity (subject to inspection reports) were divided into the following groups: cleaning and disinfection area (the correct execution of a protocol for cleaning and disinfection is difficult to control especially in dirty areas and for the peculiar activity); structure maintenance, plant and equipment area; staff training area (especially hygiene and correct information at all levels); area management of animal by-products (ABP). The results of microbiological samples on the skin to search for TMC, total coliforms, E. coli, coagulase positive Staphylococci are shown in Table 1 and the results of Salmonella spp. are shown in Table 2 and Figure 1. The results concerning the environmental swabs for the detection of TMC are shown in Table 3 and Figure 2. The results of the tests of shelf life, (comparison between data collected in 2011 and those for the year 2008), are shown in the Tables 4 and 5 and Figures 3 and 4.

\section{Discussion}

In the period under investigation the official 
veterinary of the local health unit of competence, highlighted several non-compliances, as shown by the numerous inspection reports issued. The company has quickly turned to the satisfaction of the requirements, taking into account the requirements received not as a burden but as an opportunity for improvement, and it promoted: i) the implementation of proper sanitation procedures; ii) the start of maintenance works and structural renewal; iii) the reduction of cross-contamination through functional enhancements and appropriate interventions training of skilled workers; iv) the introduction of major technological innovations.

\section{Conclusions}

The objective achieved has been an improvement of the efficiency of the activities with the reduction of problems related to the four macro-areas identified as the most sensitive (cleaning and disinfection, maintenance of plant and equipment, staff training, management of ABPs). This improvement is evidenced by the reduction in the number of
Table 1. Microbiological parameters relative to samples of chicken skin.

\begin{tabular}{|c|c|c|c|c|c|}
\hline Year & Sample (n) & $\begin{array}{c}\text { TMC } \\
\text { (log ufc/g) }\end{array}$ & $\begin{array}{l}\text { Coliforms } \\
\text { (log ufc/g) }\end{array}$ & $\begin{array}{c}\text { E. coli } \\
\text { (log ufc/g) }\end{array}$ & $\begin{array}{c}\text { STF } \\
(\log \text { ufc/g) }\end{array}$ \\
\hline 2008 & 9 & 6.46 & 3.49 & 3.01 & 2.14 \\
\hline 2009 & 47 & 6.99 & 3.11 & 3.26 & 2.25 \\
\hline 2010 & 54 & 4.79 & 2.33 & 2.26 & 1.66 \\
\hline 2011 & 51 & 4.64 & NA & NA & NA \\
\hline
\end{tabular}

TMC, total mesophilic charge; E. coli, Escherichia coli; STF, Coagulase Positive Staphylococci.

Table 2. Salmonella spp. in samples of chicken carcass skin.

\begin{tabular}{lccc} 
Year & Total samples (n) & \multicolumn{2}{c}{ Samples positive to Salmonella } \\
& & (n) & (\%) \\
2008 & 255 & 66 & 25 \\
2009 & 220 & 30 & 13 \\
\hline 2010 & 260 & 25 & 9 \\
2011 & 210 & 17 & 8 \\
\hline
\end{tabular}

Table 3. Total mesophilic count in pre-operative environmental swabs.

\begin{tabular}{lcc} 
Year & Sample $(\mathrm{n})$ & TMC $(\log$ ufc/g) \\
2008 & 413 & 3.42 \\
2009 & 606 & 3.05 \\
\hline 2010 & 621 & 1.85 \\
2011 & 643 & 1.26
\end{tabular}

TMC, total mesophilic charge.

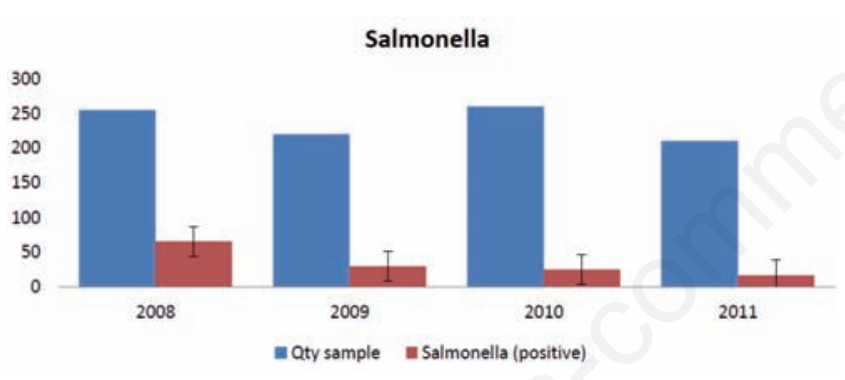

Figure 1. Salmonella spp. in samples of chicken carcass skin. Values are reported as standard deviation.

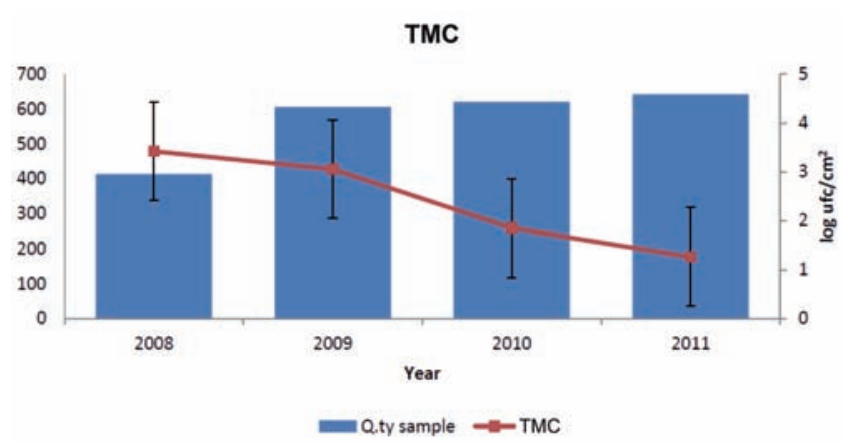

Figure 2. Total mesophilic count in pre-operative environmental swabs. Values are reported as standard deviation.

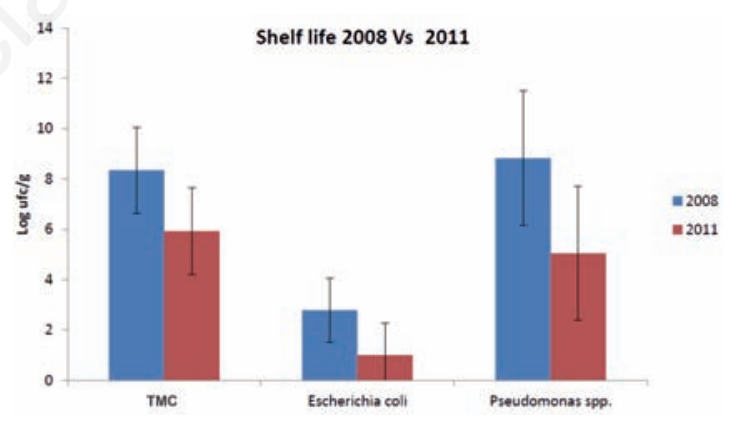

Figure 3. Shelf life of fresh products packed in container with permeable plastic wrap, relative to microbiological parameters (TMC, E. coli and Pseudomonas spp.). Values are reported as standard deviation.

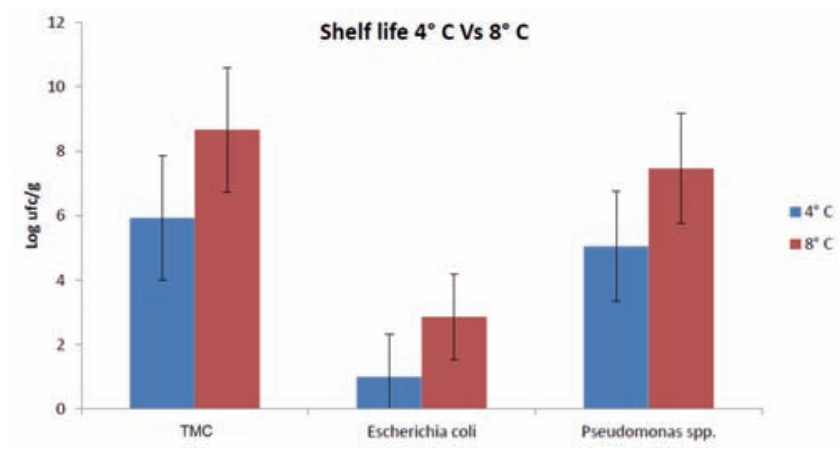

Figure 4. Shelf life tests- comparison between the values of microbiological parameters (TMC, E. coli and Pseudomonas spp.) tested at different temperatures $\left(\mathrm{T}=+4-+8^{\circ} \mathrm{C}\right)$. Values are reported as standard deviation. 
Table 4. Shelf life tests carried out in 2008 and 2011 relative to microbiological parameters total mesophilic charge, $E$. coli, Pseudomonas $\left(\mathrm{T}=+4^{\circ} \mathrm{C}\right)$.

\begin{tabular}{ccccc} 
Year & Sample (n) & TIMC $(\log$ ufc/g) & E. coli $(\log$ ufc/g) & Pseudomonas $(\log$ ufc/g) \\
2008 & 13 & 8.35 & 2.79 & 8.83 \\
2011 & 7 & 5.93 & 1.00 & 5.05 \\
\hline
\end{tabular}

TMC, total mesophilic charge; E. coli, Escherichia coli.

Table 5. Shelf life tests-comparison between the values of microbiological parameters (total mesophilic charge, $E$. coli and Pseudomonas) tested at different temperatures $(\mathrm{T}=+$ $\left.4-+8^{\circ} \mathrm{C}\right)$

\begin{tabular}{lcccc} 
Year & Sample $(\mathrm{n})$ & TIMC $(\log$ ufc/g) & E. coli $(\log$ ufc/g) & Pseudomonas $(\log$ ufc/g) \\
$2011-4^{\circ} \mathrm{C}$ & 7 & 5.93 & 1 & 5.05 \\
$2011-8^{\circ} \mathrm{C}$ & 7 & 8.66 & 2.86 & 7.46 \\
\hline
\end{tabular}

TMC, total mesophilic charge; E. coli, Escherichia coli.

inspection reports, and then the non-compliance, as well as by the gradual lowering of the level of severity and importance of these. Also, microbiological parameters tested have undergone major declines. The improvement of hygienic conditions of processing has also reduced the level of contamination by important pathogens such as Salmonella. Since 2011 the company has decided to include in its plan of self-control a specific procedure concerning the evaluation of shelf life of the products as a method of verification of the hygienic production and processing systems. The data obtained from the survey carried out systematically, randomly compared to those obtained in the absence of a specific operating procedure for 2008, have revealed that the effectiveness of the interventions also had a favourable outcome on the final quality of the product, increasing the conservative estimated average life of 12 days (i.e. additional two days). In conclusion, under Reg. CE 852/04 (European Union, 2004a), the primary responsibility for food safety is entrusted to the food business operator (FBO). The mere compliance with regulations, though adequate for the marketing of finished products, it is often limiting and certainly not very rewarding for the manufacturer. Embarking on a path of growth to quality, instead, is a much more complex and ambitious goal to reach, but far more rewarding over time. In this perspective, the competent authority has a central role to support and address. Focused activity and continued in accordance with specific objectives and fixed time periods (frequency, number, programming) is essential to engage with the FBO relationship of respect and trust. It is only a good collaboration between the two main actors in the food chain, being fully aware of their active role aimed at continuously improve that food security is effectively and efficiently guaranteed in a production system.

\section{References}

AFNOR, 2006. [Microbiologie des aliments. Dénombrement des Pseudomonas spp. dans les viandes et produits à base de viande et les volailles. Méthode de routine]. [Legislation in French]. AFNOR Regulation NF V04-504. AFNOR, La Plaine Saint-Denis, France.

European Union, 2004a. Regulation (EC) $n$. $852 / 2004$ (2004) on the hygiene of foodstuffs. In: Official Journal of the European Union, L 139, 30/04/2004.

European Union, 2004b. Regulation (EC) n. 854/2004 of the European Parliament and of the Council of 29 April 2004 laying down specific rules for the organization of official controls on products of animal origin intended for human consumption. In: Official Journal of the European Union, L 139, 30/04/2004.

European Union, 2005. Regulation (EC) n. 2073/2005 of 15 November 2005 on microbiological criteria for foodstuffs. In:
Official Journal of the European Union, L $338,22 / 12 / 2005$.

ISO, 1991. Microbiology. General guidance for the enumeration of coliforms. Colony count technique. ISO Regulation 4832:1991. International Organization for Standardization, Geneva, Switzerland.

ISO, 2004. Microbiology of food and animal feeding stuffs. Horizontal methods for sampling techniques from surfaces using contact plates and swabs. ISO Regulation 18593:2004. International Organization for Standardization, Geneva, Switzerland.

Tantillo GM, 2001. The hygienic production of meat. Edagricole, Milan, Italy.

UNI EN ISO, 2002. [Microbiologia di alimenti e mangimi per animali - Metodo orizzontale di routine per la conta di stafilococchi coagulasi- positivi - Tecnica della conta in piastra a $37 \mathrm{C}$ e conferma delle colonie]. [Legislation in Italian]. UNI EN ISO Regulation 10984-2:2002. Ente Nazionale Italiano di Unificazione, Milan, Italy.

UNI EN ISO, 2004. [Microbiologia di alimenti e mangimi per animali - Metodo orizzontale per la conta di microrganismi - Tecnica della conta delle colonie a $30^{\circ} \mathrm{C}$ ]. [Legislation in Italian]. UNI EN ISO Regulation 4833:2004. Ente Nazionale Italiano di Unificazione, Milan, Italy.

UNI EN ISO, 2008. [Microbiologia di alimenti e mangimi per animali - Metodo orizzontale per la ricerca di Salmonella spp.]. [Legislation in Italian]. UNI EN ISO Regulation 6579:2008. Ente Nazionale Italiano di Unificazione, Milan, Italy.

UNI EN ISO, 2010. [Microbiologia di alimenti e mangimi per animali. Metodo orizzontale per la conta di Escherichia coli beta glucuronidasi-positiva. Parte 2: tecnica della conta delle colonie a $44^{\circ} \mathrm{C}$ che utilizza 5 bromo-4-cloro-3- indolil beta-D-glucuronide]. [Legislation in Italian]. UNI EN ISO Regulation 16649-2:2010. Ente Nazionale Italiano di Unificazione, Milan, Italy.

Vergara A, Festino AR, Di Ciccio P, Pennisi L, Conter M, Costanzo C, Ianieri A, 2010. The managment of the domestic refrigeration: hygienic and sanitary characteristics of refrigerators from Northen and Central Italy. Rivista dell'Associazione Italiana Veterinari Igienisti 1:13-7. 